\title{
Identity status of adolescents living in institutional shelters
}

Open acess

${ }^{1}$ Laboratório de Psicologia Ambiental e Desenvolvimento Humano, Universidade Federal de São Paulo; Rua Silva Jardim, 136 - Vila Mathias - Santos/SP - CEP: 11015020.

2Departamento de Pediatria, Universidade Federal de São Paulo; Rua Botucatu, 715 - São Paulo/SP CEP: 04023-901.

32Departamento de Saúde, Universidade Nove de Julho; Rua Vergueiro, 249 - São Paulo/SP CEP: 01504-001.

${ }^{4}$ Departamento de Ciências do Mar, Universidade Federal de São Paulo; Rua Carvalho de Mendonça, 144 - Encruzilhada - Santos/SP - CEP: 11070-100.

Corresponding author: nancy.unifesp@gmail.com

Manuscript received: April 2017 Manuscript accepted: October 2017

Version of record online: December 2017

\author{
Eduardo Sales Brito', Teresa Helena Schoen², Márcia Regina \\ Fumagalli Marteleto ${ }^{3}$, Nancy Ramacciotti de Oliveira-Monteiro ${ }^{4}$
}

\begin{abstract}
Introduction: The development of adolescents living outside the environment of their families and residing in institutional shelters presents peculiar characteristics in the interactions established in their daily lives and the constitution of their identities. Erikson's psychosocial theory studies identity formation, observing exploration and commitment. Identity status can be classified as identity diffusion, foreclosure, moratorium, and identity achievement.
\end{abstract}

Objective: To evaluate identity status of adolescents living in institutional shelters.

Methods: Eighty-seven adolescents living in institutional shelters (age 12-17) individually responded to the Extended Objective Measure of the Ego Identity Status II (EOMEIS II). The data were analysed using descriptive and inferential statistics which included the following variables: gender, age range, schooling, and time of sheltering.

Results: There was a prevalence of the identity diffusion status in both genders, regardless of the length of schooling and despite the time of sheltering. There were differences in the results considering age range $(p=0,033)$.

Conclusion: Older adolescents showed greater losses in identity development, with more negative and immature states of identity, indicative of poor preparation for leaving the institution (at age 18).

Keywords: identity, adolescence, institutional shelters, identity status, EOMEIS II. 
By the end of the first decade of this century, the estimated number of children and adolescents living in institutional shelters worldwide was more than 8 million ${ }^{1}$. Brazilian documents from 2013 indicated that there were 14,989 of children and adolescents in the southeast region of Brazil, distributed in 1,087 institutional shelters ${ }^{2}$. The state of São Paulo had the largest number of those children who were in care.

Children and adolescents who live in institutional shelters are considered socially vulnerable. Living outside the environment of their families, and more than that, having their histories affected in the family ties (usually the reason for institutionalization), these children and adolescents are subject to risk factors for their development ${ }^{3}$.

National and international studies agree, pointing out the damage to the development of those who are sheltered $^{4-7}$. These studies verified the prevalence of psychological problems, loss of competence, as well as difficulties in adapting to conventional society after leaving the institutions.

Adolescence is a phase of human life characterized by major transformations and reorganizations that affect different domains of development in multiple dimensions ${ }^{8}$. With its own and common elements, the transition to adolescence involves an enormous diversity ${ }^{9}$, even within a culture and historical moment. The perspectives of individuals embedded in a problematic environmental system, such as discontinuous social relationships, broken homes, negligence, sexual or physical abuse, among many other issues, directly influence their choices and their conditions of existence ${ }^{10}$. This is the common situation in shelter services.

Institutional shelters are described by the Brazil Statute of the Child and Adolescent (ECA) ${ }^{11}$ as a place that should provide protection to children and adolescents who have had their rights violated or threatened and for whom living with their original family is considered detrimental to their development. Although the characteristic of 'transience' is forecast in shelter services, it commonly is a long stay for the ones in care, turning the institution into their main referential space where affective and social bonds are established ${ }^{12}$.

In this shelter services environment, young people experience psychosocial tasks proper to adolescence which shape a large part of their identity development ${ }^{13}$. It is during adolescence that the sense of self-identity especially flourishes with the discovery of what one will become, what one wants to do in life, what occupations or works attract them, and with whom they want to share life - the most important values or prerogatives that form the basis for subjectivity throughout life ${ }^{13}$.

Erikson $^{13}$ postulated that identity development is a process that occurs throughout life, but it rises especially during adolescence. This author understood adolescence as a period of 'psychosocial moratorium' in which individuals are offered opportunities to consider (potential) life choices without being expected to do full- time work, to have a committed romantic relationship, or to become parents - expectations of evolutionary tasks of adults which are relativized by peculiar personal, social, cultural, and historical conditions.

Marcia systematized the Erikson's psychosocial theory, presenting two essential dimensions in the formation of identity by the adolescent: exploration and commitment $^{14}$. Exploration is the dimension related to examinations and reviews of the alternatives. Through exploration, the adolescent can try out different alternatives, encountering new and/or old questions about values and different possibilities. The commitment dimension refers to relatively firm choices that are repeated and will guide future actions (in the interpersonal and/or ideological domains). Commitment is measured by the degree of personal investment that the individual has and expresses with respect to possible alternatives ${ }^{15}$.

From the interplay of these premises of exploration and commitment, related to interpersonal and ideological domains, Marcia ${ }^{14}$ proposed four statuses of identity: diffusion, foreclosure, moratorium, and identity achievement ${ }^{16}$. In the moratorium identity, the young person finds an interest in exploring various types of alternatives but does not establish a commitment to them. In the foreclosure identity, 'early' commitments occur without exploration of alternatives; in this status, the adolescent commits himself with his choices, aiming at goals guided by adults, usually parents, or their external representatives. The diffusion identity status is characterized by a lack of interest in exploring or commitment with choices. In achievement identity, the young person makes his choices and pursues goals, that is, he already has explored and reaches commitment. Adolescents pass through these four statuses, and the process of identity construction (from diffusion or foreclosure, passing through the moratorium to reach the achievement stage) generally occurs in the final years of adolescence.

González et al. ${ }^{17}$ present a subdivision of these identity statuses into two subgroups: 'active' or 'mature' status and 'passive' or 'immature' status. The moratorium and achievement identities are active or mature, corresponding to the more developed status of identity; they are associated with positive characteristics such as good level of self-esteem, autonomy, and moral reasoning. On the other hand, the status of diffusion and foreclosure are considered passive or immature, corresponding to the initial status of identity development. In the final years of adolescence, these statuses are associated with characteristics of greater fragility and/or negativity, such as low self-esteem and low moral reasoning, as well as a greater degree of conventionality and conformism.

Several studies on identity status have been performed in different cultures ${ }^{18-22}$. In Brazil, there are still few studies on the field of adolescent identity, especially on identity status ${ }^{15,16,23,24}$. In this ambit, this study has the objective of evaluating identity status in a sample of adolescents residing in institutional shelters. 


\section{METHODS}

The research had characteristics of quantitative, transverse, descriptive and correlational study.

\section{Participants}

Participating in the study were 87 adolescents age $12-17$ (Average $=14.7 ; \mathrm{DP}=1.24)$, who lived in 11 different institutional shelters in the municipalities of Sao Paulo state coast (Brazil). There were both public and private (non-governmental organizations) institutions. The sample was constituted by criteria of convenience and accessibility, which characterized it as non-probabilistic and intentional. Among those researched, $35(40.23 \%)$ were females and 52 $(59.77 \%)$ males, and $40(45.98 \%)$ were age $12-14$ and $47(54.02 \%)$, age $15-17$. Of the total number of participants, $36(41.38 \%)$ had less than two years in an institutional stay and $51(58.62 \%)$ had been in care for more than two years. Regarding their education, 23 $(26.44 \%)$ attended school until reaching the 7 th grade of elementary school and $64(73.56 \%)$ attended the 8 th or 9th grade of elementary school or were beginning high school. Seven adolescents in the age 15-17 subgroup had schooling until the 7 th grade, which indicated school delay.

\section{Instrument}

The Extended Objective Measure of the Ego Identity Status II (EOMEIS II) ${ }^{25}$, an American scale, was used to survey adolescents about identity status. Validated in several countries ${ }^{26}$, it is one of the most used instruments in studies on identity ${ }^{15}$ in adolescents and young adults. The EOMEIS II covers the ideological and interpersonal domains. Respondents rate 64 items on a 6-point Likert scale, ranging from 'totally disagree' to 'strongly agree'. The version used for this research was the Brazilian semantic adaptation of EOMEIS II ${ }^{22}$, with a cut-off value adapted for the São Paulo sample ${ }^{15}$. The sum of the responses marked by the individual enables the researcher to trace the identity status (identity diffusion, moratorium, foreclosure or identity achievement) in which the respondents were at the time they filled out the scale. The instrument takes approximately 30 minutes to complete.

\section{RESULTS}

The descriptive data on identity status showed a prevalence of diffusion identity, with $63.2 \%$ of the adolescents in the sample in this status, followed by moratorium $(21.8 \%)$, foreclosure $(11.5 \%)$, and identity achievement $(3.5 \%)$.

Inferential analysis showed that there were no significant differences in most variables when compared. There was only a significant difference ( $\mathrm{p}$ $=0.033$ ) between older and younger adolescents in the results of identity status. Table 1 shows that in the younger adolescents (age 12-14), diffusion status was predominant $(50 \%)$. There also was a predominance $(74.5 \%)$ of this same status among older adolescents

\section{Procedures}

The study followed ethical norms of research with human beings which have been approved by CEP-UNIFESP ( $\mathrm{n}^{\mathrm{o}}$ 30478714.1.0000.5505). Personal contacts were made to present the research proposal to the boards of institutional shelters in the municipalities of Sao Paulo state coast. After acceptance, the institutional leaders collected signatures of consent using the Free Informed Consent Form (TCLEs). The adolescents were presented with the research proposal and attendance invitations. Those who agreed to participate in the study signed an assent form. Before administering the EOMEIS II, researchers collected participant information such as their names, dates of birth, time of sheltering, school year they were attending, and conditions for contacting family members.

The EOMEIS II was given individually by the first author of this article. The day and time of the administration, conducted in private at the shelter facility, was arranged previously with the adolescents and the technical teams. The survey occurred as an interview to minimize the effects of possible difficulties in reading and understanding of the statements in EOMEIS II. The average time of application was 45 minutes.

The results of the EOMEIS II were analysed by variable: gender, age range (12-14 years/15-17 years), schooling (up to and including the 7 th grade/after the 7 th grade) and time of sheltering (up to two years/ more than two years). After the database composition, descriptive and inferential analyses were performed using the Statistical Package for Social Sciences (SPSS) software. Inferential analysis was performed using Fisher's Exact Test (at a significance level of 0.05 ) to verify the significance between the variables and the identity status. The descriptive measures for the independent variables related to identity status were used from a binary comparison between them.

(age 15-17). Table 1 shows a predominance of the diffusion status for males and females in the sample. Three males were identified in the identity achievement status.

Data presented on the educational variable in Table 1 indicates that there also was a predominance of adolescents in the diffusion status, unrelated to the years of study. On the other hand, the diffusion identity also was indicated, regardless of the time the adolescent resided in the institutional shelters (less than or greater than two years). 
Table 1: Distribuition sample by state of identy, age group sex, education and time of sheltherig

\begin{tabular}{|c|c|c|c|c|c|}
\hline & Diffusion & before closing & Moratorium & Identy & Total \\
\hline \multicolumn{6}{|c|}{ Age group ${ }^{(1)}$} \\
\hline \multirow[t]{2}{*}{12 a 14 years } & 20 & 8 & 11 & 1 & 40 \\
\hline & $50 \%$ & $20 \%$ & $27,5 \%$ & $2,5 \%$ & $100 \%$ \\
\hline \multirow[t]{2}{*}{15 a 17 years } & 35 & 2 & 8 & 2 & 47 \\
\hline & $74,5 \%$ & $4,3 \%$ & $17,0 \%$ & $4,3 \%$ & $100 \%$ \\
\hline \multicolumn{6}{|c|}{$\operatorname{Sex}^{(2)}$} \\
\hline \multirow[t]{2}{*}{ Female } & 19 & 6 & 10 & 0 & 35 \\
\hline & $54,30 \%$ & $17,14 \%$ & $28,56 \%$ & $0 \%$ & $100 \%$ \\
\hline \multirow[t]{2}{*}{ Male } & 36 & 4 & 9 & 3 & 52 \\
\hline & $69,20 \%$ & $7,70 \%$ & $17,30 \%$ & $5,80 \%$ & $100 \%$ \\
\hline \multicolumn{6}{|c|}{ Education $^{(3)}$} \\
\hline \multirow[t]{2}{*}{ Up to $7^{\circ}$ year } & 16 & 4 & 3 & 0 & 23 \\
\hline & $69,60 \%$ & $17,40 \%$ & $13 \%$ & $0 \%$ & $100 \%$ \\
\hline \multirow[t]{2}{*}{ Above $7^{\circ}$ year } & 39 & 6 & 16 & 3 & 64 \\
\hline & $60,90 \%$ & $9,40 \%$ & $25 \%$ & $4,70 \%$ & $100 \%$ \\
\hline \multicolumn{6}{|c|}{ Time of Sheltherig ${ }^{(4)}$} \\
\hline \multirow[t]{2}{*}{ Up to 2 year } & 24 & 6 & 6 & 0 & 36 \\
\hline & $66,7 \%$ & $16,7 \%$ & $16,7 \%$ & $0 \%$ & $100 \%$ \\
\hline \multirow[t]{2}{*}{ Above 2 years } & 31 & 4 & 13 & 3 & 51 \\
\hline & $60,8 \%$ & $7,8 \%$ & $25,5 \%$ & $5,9 \%$ & $100 \%$ \\
\hline \multirow[t]{2}{*}{ Total } & 55 & 10 & 19 & 3 & 87 \\
\hline & $63,2 \%$ & $11,5 \%$ & $21,8 \%$ & $3,4 \%$ & $100 \%$ \\
\hline
\end{tabular}

(1) $p=0,033 ;(2) p=0,152 ;(3) p=0,383 ;(4) p=0,276$

\section{DISCUSSION}

The sample studied presented the highest number of adolescents in the 15-17 age group, with different conditions regarding the time of sheltering and in 11 different and diversified (in their characteristics) institutional shelters in Sao Paulo state coast. Although constituted by criteria of convenience and accessibility, this sample presented similar characteristics to other Brazilian studies with adolescents in institutional care. In a study carried out in Porto Alegre (RS) with sheltered adolescents, for example, there also were more males $^{12}$ and the average age of participants (15) was similar to this study (14.7).

The time of sheltering of the adolescents in this study varied from a few weeks to ten years, a situation also present in the study of Gonzalez et al. ${ }^{17}$ Likewise, Silva ${ }^{26}$ identified an institutional length of stay that surpassed the due time by legislation (up to two years) in $52.6 \%$ of the children and adolescents who were researched. Data from 2011, pointed out in the National Survey of Children and Adolescents residing in Institutional Shelters ${ }^{27}$, showed that in the southeast region, the maximum time of sheltering was 17.6 years. This longer time confronts resolutions of the $\mathrm{ECA}^{11}$ regarding the maximum period for institutionalized shelter. In the current study, $31 \%$ of adolescents lived for more than two years in institutional shelters.

According to the classification of González et $a l .{ }^{17}$ the diffusion and foreclosure statuses are considered negative pole or passive. Diffusion was the identity status found in most adolescents researched (63.2\%), but the negative emphasis of the identity status was found in older adolescents of the sample $(57.4 \%$ in the diffusion status and $19.1 \%$ in the foreclosure status). These results differed from those in other studies that researched adolescents' identity status, with a prevalence of moratorium status ${ }^{15,26}$, as a more mature and active status in adolescence.

The diffusion identity is characterized by a low degree of commitment and lack of exploitation in different domains. At the end of adolescence ${ }^{11}$, this status may represent a failure to reach a commitment after a period of exploration ${ }^{14,16,17}$ or even losses on explorations. Some young people do not feel the need and/or desire to explore alternatives; others do not have favourable conditions for this, which seems to have been the situation of those researched. The diffusion identity, at a later stage of adolescence, represents patterns of apathy, lack of interest, and difficulties in social roles and in their own feelings ${ }^{13}$.

When adolescents reach age 18 , they must leave the institutional shelters. Thus, an immature identity status found in older adolescents (foreclosure and diffusion) point to concerns. Without proper family support and in a situation of social vulnerability (due to 
insufficient income and difficulties for employability and housing), leaving the institutional shelters requires these young people to have the force and inner resources to cope with the vicissitudes of adaptation outside the walls of the institution and entrance of adult life ${ }^{6}-$ resources not indicated in the verification of their identity status.

Several of the adolescents who were leaving the institution at the earliest opportunity had school delays, a loss also noted in the National Survey of Children and Adolescents in Shelter Services, published in 201127. For Brazilian youth without schooling deficits, in general terms, the last years of adolescence coincide with the period of high school graduation and introduction to higher education or technical courses a situation not found in the researched young people in this study, with indications of lack of preparation in the skills required for their admission to the labour market.

Aiming to assess identity status in adolescents living in institutional shelters, and covering conceptual boundaries on adolescence and the development of identity, this study tried to contribute to studies on adolescents who live in a peculiar context of social vulnerability, children and young people not raised and looked after by their families. Assuming methodological limits, the study does not seek generalizations even if it endorses the results of other investigations in the verification of developmental problems in adolescents in care, highlighted here those of identity development.

Continuing research on identity status in adolescents and young adults in a condition of social vulnerability is suggested to better guide the interventions needed to promote this group's positive development. The expansion of knowledge about the difficulties of development faced by adolescents in care may be an alert for the establishment and increment of specific public health actions aimed at this socially vulnerable population.

\section{CONCLUSION}

The diffusion identity status was prevalent among the researched adolescents in care. Gender, time of sheltering (up to or more than two years) and education (up to the 7 th grade or higher than the 7 th grade) did not indicate any influence on identity status. In turn, older

\section{REFERENCES}

1. Save the Children. Keeping children out of harmful institutions: Why we should be investing in familybased care. Londres: 2009. [cited 2017 Jan 21]. Available from:https://www.savethechildren.org.uk/ sites/default/files/docs/Keeping_Children_Out_of_Harmful_Institutions_Final_20.11.09_1.pdf

2. Brasil. Conselho Nacional do Ministério Público (CNPM). Um olhar mais atento aos serviços de acolhimento de crianças e adolescentes no País: Resolução n 71/2011. Brasília: CNPM; 2013.

3. Tottenham N. Risk and developmental heterogeneity in previously institutionalized children. J Adolesc Health. 2000;51(2 Suppl.):S29-33. DOI: http://dx.doi.org/10.1016/j.jadohealth.2012.04.004

4. Fernandes AO, Oliveira-Monteiro NR. Psychological indicators and perceptions of adolescents in residential care. Paidéia. 2016;26(63):81-9. DOI: http://dx.doi.org/10.1590/1982-43272663201610

5. Marinkovic JA, Backovic D. Relationship between type of placement and competencies and problem behavior of adolescents in long-term foster care. Child Youth Serv Rev. 2007;29(2):216-25. DOI: http://dx.doi.org/10.1016/j.childyouth.2006.08.004

6. Naqshbandi M, Sehgal R, Hassan F. Orphans in orphanages of Kashmir "and their psychological problems". Int NGO J. 2012;7(3):55-63. DOI: http://dx.doi.org/10.5897/INGOJ12.016

7. Oliveira-Monteiro NR, Nascimento JOG, Montesano FT, Aznar-Farias M. Competência, problemas internalizantes e problemas externalizantes em quatro grupos de adolescentes. Psico-USF. 2013;18(3):427-36. DOI: http://dx.doi.org/10.1590/S1413-82712013000300009

8. Organização Mundial da Saúde (OMS). Health for the world's adolescents: A second chance in the second decade. Geneva: World Health Organization; 2014. [cited 2017 Jan 21]. Available from: http:// apps.who.int/adolescent/second-decade/files/1612_MNCAH_HWA_Executive_Summary.pdf

9. Borges LS, Alencar, HM. Violências no cenário brasileiro: fatores de risco dos adolescentes perante uma realidade contemporânea. J Hum Growth Dev. 2015;25(2):194-203. DOI: http://dx.doi.org/10.7322/jhgd.103015

10. Schmid M, Goldbeck L, Nuetzel J, Fegert J. Prevalence of mental disorders among adolescents in German youth welfare institutions. Child Adolesc Psychiatry Ment Health. 2008;2(1):2. DOI: http://dx.doi.org/10.1186/1753-2000-2-2

11. Brasil. Presidência da República. Lei $n^{\circ} 8.069$ de 13 de julho de 1990. Dispõe sobre o Estatuto da Criança e do Adolescente e dá outras providências. Diário Oficial da República Federativa do Brasil. 1990. 
12. Gonzalez AC, Wathier-Abaid JL, Dell'Aglio DD. Adolescência, acolhimento institucional e convivência familiar: Um retrato sobre a garantia de direitos. In: Magalhães CMC, Cavalcante LIC, Pontes FAR, Silva SSC, Corrêa LS. Contextos ecológicos do desenvolvimento humano I. Belém: Paka-Tatu; 2011.

13. Erikson EH. The life cycle completed. New York: Norton \& Company; 1997.

14. Marcia JE. Development and validation of ego identity status. J Pers Soc Psychol. 1966;3(5):551-8. DOI: http://dx.doi.org/10.1037/h0023281

15. Schoen-Ferreira TH, Aznar-Farias M, Silvares EFM. Desenvolvimento de identidade em adolescentes estudantes do Ensino médio. Psicol Reflex Crit. 2009;22(3):41-8. DOI: http://dx.doi.org/10.1590/S0102-79722009000300002

16. Aznar-Farias M, Schoen-Ferreira TH. Estados de identidade: uma análise da nomenclatura. Aletheia. 2007;(26):62-6.

17. González ZJJ, Cuéllar AI, Miguel JMT, Desfilis ES. El desarrollo de la identidad en la adolescencia y adultez emergente: Una comparación de la identidad global frente a la identidad en dominios específicos. An Psicol. 2009;25(2):316-29.

18. Solomontos-Kountouri O, Hurry J, Peck S. Political identity types: the role of the content and the context on identity. Neapolis University Pafos; 2015. [cited 2017 Jan 21]. Available from: http://hephaestus.nup. ac.cy/bitstream/handle/11728/7096/Political-Identity-Types.pdf?sequence=1\&isAllowed=y

19. Cid MT, Espadalé MNP, Carreras FB, Fernández LM. Estudio sobre el desarrollo de la identidad em la adolescência. Tendencias Pedagógicas. 2013;(21):211-4.

20. Sandhu D, Singh B, Tung S, Kundra N. Adolescent identity formation, psychological well-being, and parental attitudes. Pakistan J Psychol Res. 2012;27(1):89-105.

21. Sandhu D. Predictive factors of health-risk behaviours among male adolescentes. Pakistan J Psychol Res. 2015;30(1):1-19.

22. Jones RM, Vaterlaus JM, Jackson MA, Morrill TB. Friendship characteristics, psychosocial development, and adolescent identity formation. Pers Relatsh. 2014;21(1):51-67. DOI: http://dx.doi.org/10.1111/pere.12017

23. Schoen-Ferreira TH, Aznar-Farias M, Silvares EFM. A construção da identidade em adolescentes: Um estudo exploratório. Estud Psicol. 2003;8(1):107-15. DOI: http://dx.doi.org/10.1590/S1413-294X2003000100012

24. Schoen-Ferreira TH, Meneghelli N, Aznar-Farias M. Validação semântica do Extended Objective Measure of Ego Identity Status 2 - EOMEIS-2. In: Congresso Brasileiro de Avaliação Psicológica. Porto Alegre: Instituto Brasileiro de Avaliação Psicológica; 2005.

25. Bennion LD, Adams GR. A revision of the extended version of the Objective Measure of Ego Identity Status: An identity instrument for use with late adolescents. J Adolesc Res. 1986;1(2):183-198. DOI: http://dx.doi.org/10.1177/074355488612005

26. Bergh S, Erling A. Adolescent identity formation: A swedish study of identity status using the EO-MEISII. Adolescence. 2005;40(158):377-96.

27. Constantino P, Assis SG, Mesquita VSF. Crianças, adolescentes e famílias em SAI. In: Assis SG, Farias LOP. Levantamento nacional das crianças e adolescentes em serviço de acolhimento. São Paulo: Hucitec; 2013; p.161-220. 


\section{Resumo}

Introdução: O desenvolvimento de adolescentes que vivem fora do convívio familiar, por situação de acolhimento institucional, tem características peculiares nas interações estabelecidas em suas vidas cotidianas e na constituição de suas identidades. A teoria psicossocial de Erikson estuda o desenvolvimento da identidade observando a exploração e o compromisso. Os estados de identidade podem ser classificados em difusão, pré-fechamento, moratória e identidade estabelecida.

Objetivo: Avaliar os estados de identidade de adolescentes que vivem em situação de acolhimento institucional.

Método: Participaram 87 adolescentes (de 12 a 17 anos) em situação de acolhimento, que responderam ao Extended Objective Measure of the Ego Identity Status II (EOMEIS II), em aplicações individuais. Dados foram tratados de forma descritiva e inferencial pelas variáveis: sexo, faixa etária, escolaridade, e tempo de acolhimento.

Resultados: Houve prevalência do estado de difusão de identidade, em ambos os sexos, independentemente do tempo de escolarização, e a despeito do tempo de acolhimento. Houve diferença nos resultados considerando faixa etária $(p=0,033)$.

Conclusão: Os adolescentes mais velhos sinalizaram maiores prejuízos no desenvolvimento da identidade, com prevalência de estados mais negativos e imaturos de identidade, indicativos de despreparo para saída da instituição (aos 18 anos).

Palavras-chave: identidade, adolescência, acolhimento institucional, estados de identidade, EOMEIS II.

- The authors (2017), this article is distributed under the terms of the Creative Commons Attribution 4.0 International License (http://creativecommons.org/licenses/by/4.0/), which permits unrestricted use, distribution, and reproduction in any medium, provided you give appropriate credit to the original author(s) and the source, provide a link to the Creative Commons license, and indicate if changes were made. The Creative Commons Public Domain Dedication waiver (http://creativecommons.org/publicdomain/ zero/1.0/) applies to the data made available in this article, unless otherwise stated. 